07.00.06

Андреева Татьяна Валентиновна

Историк искусства, диплом специалиста МГУ им. М.В.Ломоносова

394018 Воронеж, ул. Куколкина 11, кв. 644

Тел. 89192319354

tatiana.aspasia@gmail.com

Аннотация. Фестский диск - это известный артефакт, происхождение и интерпретация которого вызывает споры не одно десятилетие. На сегодняшний день большинством исследователей принято, что диск сделан на Крите, миниатюрными печатями, письмо слоговое, язык не известен. Мы предлагаем взглянуть на этот предмет с помощью увеличительного стекла, и заметить детали, которые не могли видеть ученые начала 20 века. При детальном рассмотрении под лупой оказалось, что повторяющиеся знаки разные, а не сделаны одним клише, что подвело автора статьи к выводу о ручном исполнении значков. Предлагается рассмотреть текст как пример пиктографического письма, изобретенного в мастерских Египта. Для иллюстраций использованы увеличенные фотографии Фестского диска, сделанные в музее Крита.

Ключевые слова: Фестский диск, Крит, пиктография, Египетское искусство, гончарное мастерство, древности.

The Phaistos disk is a well-known artifact, the origin and interpretation of which has been controversial for decades. To date, most researchers have accepted that the disk was made in Crete, with miniature seals, the letter is syllabic, the language is not known. We suggest looking at this object with a magnifying glass, and noticing details that scientists of the early 20th century could not see. When examined in detail under a magnifying glass, it turned out that the repeated signs are different, and not made by one cliche, which led the author of the article to the conclusion about the manual execution of the icons. It is proposed to consider the text as an example of pictographic writing, invented in the workshops of Egypt. The 
illustrations are enlarged photographs of the Phaistos disk taken in the Museum of Crete.

Keywords: Phaistos disk, Crete, pictography, Egyptian art, pottery, antiquities.

\section{Фестский диск. Взгляд из 21 века.}

Часть 1. Египетское происхождение знаков.

Часть 2. Технологии: ручная отрисовка с цветовой обработкой.

Часть 3. Два уровня чтения знаков пиктографической письменности.

Часть 4. Предшественники диска - игра Мехен. Назначение диска оракул или гадательный священный предмет.

Фестский диск - уникальный памятник письменности, обнаруженный в 1907 в городе Фест на острове Крит в одной из комнат дворца. Вокруг данного артефакта до сих пор не умолкают споры ученых: необычная форма предмета, качество его обработки, сами символы и способ их записи рождают множество противоречий.

Основное внимание как ученые, так и любители уделяют дешифровке. В ходе многолетней работы были выявлены следующие положения:

символы на диске представляют собой слоговое письмо

сам артефакт был изготовлен на острове Крит

знаки были получены путем оттиска специальными штампами

язык близок линейному письму А или Б [2, л. 135].

Более подробно с анализом теорий и дешифровок можно ознакомиться в работе Юрия Откупщикова [1, с.23]. 
Данная же статья написана с целью опровержения вышеизложенных выводов.

\section{Часть 1.Происхождение символов}

В данной статье мы собрали подборку изображений, иллюстрирующую знаки с диска и изображения их египетских аналогов. Мы сделали это с целью показать идентичность символов с диска изображениям египетских фресок. Нами были использованы фотографии фресок и рельефов региона столицы Среднего Царства - Фив. Храмы, из которых взяты копии: Рамессеум, Поминальный храм Сети 1, заупокойный храм Хатшепсут, храм Тутмоса Ш, древние храмы Дендеры.

На диске нами были выявлены основные знаки, с помощью которых представляется возможность определить время и место изготовления памятника:

- так называемая богиня Таурт;

• домик, который также называют в публикациях ульем;

- корабль.

Таурт, или по гречески - Тоэрис - египетская богиня-бегемотиха [3 л. 135]. По нашему мнению, за богиню принято считать жену правителя страны Пунт, царя Пареху по имени Ати, с фрески в храме Хатшепсут. Именно она является той пышной женщиной с изображения. Перед ней расположено изображение ее супруга, а позади - дочери, которая также, как и мать, страдает от стеатопигии повышенного отложения жира на ягодицах (Таблица 3: 2, таблица 4: 2, таблица 5: 2).

"Дом", изображенный на диске, является характерной постройкой для некоторых регионов Африки. Похожее жилище есть на рельефе из того же храма женщины-фараона в Луксоре (Таблица 1: 7).

Корабль используется на диске несколько раз и напоминает известные изображения египетских кораблей в разных храмах, в том числе и в постройках Среднего царства.

Так, сходство самых часто встречающихся символов позволяет нам предположить, что диск был изготовлен в Египте во времена правления 
фараонов Хатшепсут и Тутмоса Ш. Иными словами, мастера, работающие над артефактом, не только хорошо знали убранство египетских храмов, но, возможно, также принимали участие в создании подобных памятников письма на их стенах.

В данной статье приведено порядка 19 изображений знаков с диска и параллельные им изображения из египетских храмов (Таблицы 1 - 3). Остальные образы тоже можно найти на стенах храмов в Египте. Не приводятся ради экономии места, так называемые кот-кошка, птица и ряд других знаков, параллели которым можно легко найти в египетской иероглифике.

Часть 2. Технологии: ручная отрисовка с цветовой обработкой.

Мы предполагаем, что диск был создан египтянином, участвовавшим в экспедиции в Пунт, или иностранцем, для которого такая форма предмета была привычной.

Однако, несмотря на данные предположения, все равно возникает вопрос: как удалось получить такое совершенное произведение? Искусством это не назовешь, скорее, скажем - выразительный предмет гончарного мастерства.

Первое, на что сразу можно обратить внимание - это изящные, легко опознаваемые образы, прорисованные на диске: морда кошки, птицы, фигуры людей и т. д. Эти образы повторяются многократно. Видимо, именно это дало основание первым исследователям полагать, что знаки создавались при помощи штампов [4, с. 135].

Нам же представляется это мнение ошибочным по ряду следующих причин:

1. Сделать печати такого размера даже сейчас нелегко. Требуется высокоточный станок, способный идентично повторять все мельчайшие детали изображения.

2. Ни одного подобного артефакта на огромном пространстве Евразии древнего мира найдено не было, что говорит нам об уникальности самого предмета.

3. Изображения, созданные печатью, абсолютно одинаковы. А как выглядят наши знаки, если их рассматривать параллельно? (Таблица 4). Видно, что каждый знак отличается от соседнего по ряду деталей: ширина и глубина 
оконтуривающей линии, разные углы наклона у прямых линий друг к другу и другие очевидные несоответствия.

Наши наблюдения и персональный опыт гончарных работ показывают, что каждый значок сделан рукой мастера-гончара по первоначальному эскизу. Отсюда и незначительные огрехи, связанные с дрожанием руки и неточностью человеческого зрения. На повторяющихся изображениях одни и те же линии могут отличаться по силе нажима, что становится очевидным при внимательном рассмотрении.

Путем детального рассмотрения знаков, изображенных на диске (Таблица 5), нами были выведены некоторые предположения относительно его изготовления и нанесения символов.

Для начала острым предметом выполнялись линии, после которых прорисовывались ряды точек. Таким образом получались объемные углубленные линии, делящие сегменты диска. По контуру знак очерчивался белой краской. Качество работы кажется невероятным, но только для тех, кто не знаком с историей и культурой Древнего Египта.

Для создания знаков керамисты применяли технологии работы с глиной и камнем, встречаемые в ряде артефактов неолитических культур, высочайшие достижения мастеров широко известны по коллекциям статуй и рельефов Древнего царства в музеях Европы и Америки. [5, с. 135].

Орудия труда были миниатюрными, подобные тем, что применяются в хирургии сейчас. Некоторые операционные инструменты из Древнего Египта можно также видеть в музеях.

Подводя итог главе, мы можем заключить, что диск был выполнен опытными мастерами, знакомыми с тысячелетними ремесленными традициями высокого уровня. Также, учитывая сходство знаков на диске с изображениями символов на стенах египетских храмов, мы вновь обращаем внимание на тот факт, что изготовлен памятник был с большой вероятностью именно в Египте.

Часть 3. Два уровня значения знаков пиктографической письменности.

При внимательном рассмотрении знаков можно обнаружить следующее: каждое изображение является составной частью другой, большей картины. Так происходит от самых мелких деталей, которые можно рассмотреть только под микроскопом, до более крупных фигур. 
Так, мы можем наблюдать мелкие детали в углах знака, подкрашенные сиреневым цветом. Это часто головы, где легко опознаются носы (и-или) клювы, и глаз.

Часто в углублении контура основной фигуры читается «змея», обязательно с двумя головами, вторая из которых расположена на самом конце хвоста (Таблица 6: 1). Все «фигуры второго уровня», как мы условно обозначили эти детали, имеют две головы - обязательно по крайним точкам своего тела. При этом те образы, которые занимают всю поверхность главного знака, выделяются белой краской и могут подчеркиваться дополнительными штрихами или линиями (Таблица 7: 5,6).

На каждом знаке Фестского диска имеется от двух-трех до восьми-десяти таких знаков, размеры которых уменьшаются по мере удаления от центра основного знака. Знак "второго уровня" имеет мелкие изображения «третьего уровня» - их глаз или ухо (Таблица 6). При рассмотрении через лупу изображение «третьего уровня» оказывается головой еще одного существа.

В поисках объяснения такого явления мы исследовали фрески и рельефы египетских храмов и обнаружили схожий феномен на отдельных иероглифах. (Таблица 8). Возможно, с осторожностью следует указать на преемственность определенной изобразительной традиции.

Отметим, что на диске использованы пять разных красок: белая - для подчеркивания контура знаков; золотая или медная - для выделения некоторых изображений, которые прорисованы на основном знаке около его края; сиреневая чаще всего проявляется в углублениях основного контура знаков, где они подчеркивают мелкие значки. По полю самого диска можно различить области, покрытые темно-коричневой и светло-коричневой краской. На обеих сторонах нереставрированного диска легко заметить, что места с сиреневой и медной краской были скрыты под слоем патины, это объясняется тем, краска содержит значительное количество металлов.

Автору представляется два возможных объяснения такой многоуровневой системы знаков: декоративная и смысловая.

Первый вариант относится $\mathrm{K}$ подходу $\mathrm{K}$ изображениям как $\mathrm{K}$ произведениям ремесла (искусства), то есть дополнительные изображения служат своеобразным украшением основного образа.

Вторая версия ведет к размышлениям о значении самих знаков. Так, ученые на сегодня согласились, что письмо на диске представлено сорока пятью повторяющимися знаками. Это такие привычные нам бытовые образы, как 
животные, птицы, сосуд, нож, секира и прочие. Так, они являются обычными образами, используемыми в других системах письма, относящихся к пиктографическому. Однако записи с фестского диска ученые относят к слоговой системе письма. [6, с. 135].

Мы выдвинули иное предположение. Мелкие образы, которые очевидно видны на знаках, сделаны не для декорации, а дополняют или даже меняют значение основного знака. Тогда получается, что на Фестском диске столько разных рисуночных знаков, сколько насчитывается - около двухсот пятидесяти. Это дает нам возможность говорить о логографическом письме, где каждый знак обозначает то или иное слово. Такую мысль высказывали исследователи и раньше, но она не была воспринята научным сообществом.

В пиктографическом письме знаки означают обычно то, что они изображают. Если нарисована нога, то принимается, что рисующим (пишущим) нужно было изобразить ногу. Но если посмотреть шире, то легко понять, что нога на диске, возможно, имела смысл «идти», а, может быть, и какие-то другие значения в зависимости от контекста. Таким образом, мы не можем исключить использование на диске именно логографики.

Часть 4. Предшественники диска - игра Мехен. Назначение диска оракул (и-или) гадательный священный предмет.

В Древнем царстве была популярная игра - Мехен. Играли в нее на столике с выгравированной или инкрустированной на нем свернувшейся кольцом змеей. Голова находилась в центре, а тело по всей длине было разделено на клетки. Существовали используемые для игры каменные столикизмеи, некоторое число которых дошло до наших дней (Таблица 8).

В Среднем царстве упоминания об игре теряются. Возможно, популярными стали другие развлечения. А форма диска в виде исключения была использована неизвестными мастерами для создания нашего загадочного предмета.

Теперь необходимо вспомнить, что игры в Древнем Египте были неразрывно связаны с общением с загробным миром, с духами и богами. В каждой гробнице есть фрески и рельефы, указывающие на это: умерший играет сам с собой, (часто в игру Сенет) [6, с. 135].

Представляется логичным предположить, что круглый диск был использован в качестве магического или культового предмета. Известно, что египтян считают если не создателями первых магических систем, то людей, 
практиковавших древнюю магию. Они верили во всевозможные астрологические прогнозы, общались с духами предков, наделяли своих многочисленных богов самыми невероятными атрибутами [7, л. 135].

Эти знания и дали нам возможность предположить, что Фестский диск это своеобразный оракул, гадательный магический предмет, по которому можно было определять будущее или же получать какую-либо иную информацию.

Данный вывод мы подкрепляем следующими аргументами:

1.Тексты бытового, исторического и иного характера обычно фиксировались на подходящих для этого формата носителях. Для времени, о котором мы говорим, применялись таблички прямоугольной формы.

2. Не известны тексты, написанные на круглых носителях. Есть два-три предмета более позднего времени, в том числе этрусские, сделанные из металла, где присутствует текст: гадательная карта гаруспиков в виде печени с несколькими значками, например. Были критские надписи, сделанные по кругу, но они очень небольшие - несколько значков: кольцо из Мавро Спелио, глиняная чаша из Кносса с надписью на дне линейным письмом А [8, с. 135]. Все упомянутые предметы невозможно сопоставлять с диском из Феста. [9, с. 135].

В продолжение второго пункта следует упомянуть также о том, что религия в Египет распространилась из Вавилона и Ассирии в виде некой первоначальной истины. И Египет эту истину сохранил, однако жрецы считали, что истина эта слишком драгоценна, чтобы передавать ее толпе, поэтому они тщательно хранили ее для себя и для своей касты. Они одни знали тайное значение символов, людям же позволяли видеть только внешние знаки. Именно этим положением мы можем объяснить непривычную форму записи, а также подкрепить положение о том, что артефакт создавался именно вручную, под запрос египетских жрецов и повторение подобного произведения было бы как минимум запретным.

Ранее было высказано предположение, что на диск нанесена информация пиктографическим письмом. Однако использовать такой вид письма для исторической летописи было бы проблематично, к тому же, на то время (17 век до н.э.) уже была распространена клинопись, с помощью которой исторические события могли быть зафиксированы более детально. Для записи же краткой информации, вроде пророчеств, логографическое письмо было очень удобно [10, л. 135].

Сам диск очень тщательно расчерчен на фрагменты, об этом говорят разделительные линии этого своеобразного текста-змеи. Мы предлагаем 
рассматривать сегменты диска как отдельные короткие смысловые ключи, самодостаточные и законченные.

Для чтения пикрографической информации не надо знать язык писавшего, каждый смотрящий интерпретирует фрагмент в соответствии с уровнем своего понимания и образования.

Так, мы можем сделать вывод о том, что диск находился в египетском храме какое-то время, где с ним имели дело жрецы-гадатели. Они использовали его, скорее всего, предсказывая по знакам первого и второго уровня. Для более простого варианта предсказания было достаточно опираться на крупные знаки, не учитывая мелкие добавления на этих знаках. Но одна историческая эпоха сменилась новой, где диск не нашел своего места, или он был увезен завоевателями, купцами, любителями истории на Крит.

Внимание: то, что вы прочтете ниже, выделенное знаками « " - это фантазия автора. Это гипотетический вариант интерпретации нескольких пиктографических надписей. Процесс гадания, по нашему мнению, мог происходить так:

«Бросалась игральная кость, на которой были значки от одного до шести. Если выпадала цифра три, то, начиная с нижней ячейки, с которой начиналось гадание (Таблица 6) считались три сегмента. Третий и был ответом на заданный вопрос. Но в таком случае, необходимо было всего шесть сегментов, поскольку на кости есть точки от одного до шести. Здесь можно вспомнить известное философско-историческое творение - «Книга перемен». Система получения номера ответа совершенно иная, а мы же ссылаемся на китайскую мудрость по другой причине. Когда запрашиваемый получает основную цифру ответа, который ему непонятен или нужно расширенное толкование, ему предоставляется дополнительная информация. Так и в нашем случае: если ответ после одного бросания будет недостаточным, можно бросить кость еще раз, для получения подсказки. Мы отобрали наугад сегменты с Фестского диска, начиная с двух значков, до максимального количества - семи.

Голова змеи: два значка (Таблица 7), волны-рыба: расслабленный отдых у воды.

Три знака (Таблица 8), шагающий человек, крупная рыба, голова кота: переезд в сельскую зону, с домашними животными и рыбной ловлей.

Четыре знака: рыба, крокус, идущий человечек, кипарис: переезд в благословенные края, где цветы и деревья, много еды.» 
Заключение: подводя итог, заметим, что по нашему мнению, Фестский диск был создан во времена, последовавшие за экспедицией в страну Пунт, организованной царицей Хатшепсут. То есть в Среднем царстве, что совпадает с заключениями других исследователей артефакта.

Страной изготовления скорее всего был Египет, что можно предположить, учитывая сходства знаков диска и египетских иероглифов, а также присутствие в Египте выдающейся скульптурной и керамической традиции. Технология изготовления была единой как для диска, так и для других глиняных изделий того времени, таким образом нет никаких оснований для рассмотрения вопроса о печатях.

Назначение диска: с осторожностью предполагаем, что это был объект, служащий для получения предсказаний. Знаки представляют собой пиктографические записи, поэтому вопрос о языке диска не поднимается. По той же причине не представляется существенным рассматривать проблему направления чтения знаков: в логограммах порядок значков может не иметь значения. 

+Таблица 1 . Критские знаки и их параллели в Египте

Table 1 Cretan signs and their corresponding Egyptian
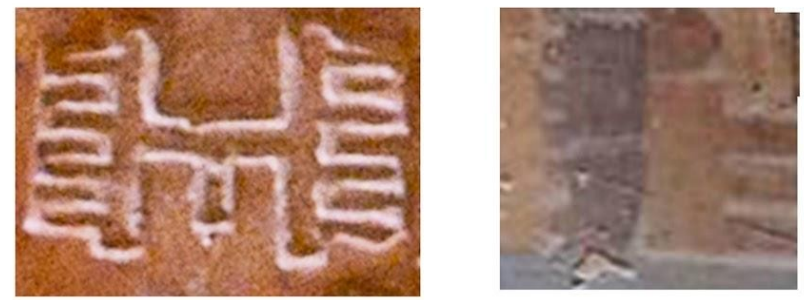

1. План дворца или колесница

1. Palace plan or charriot

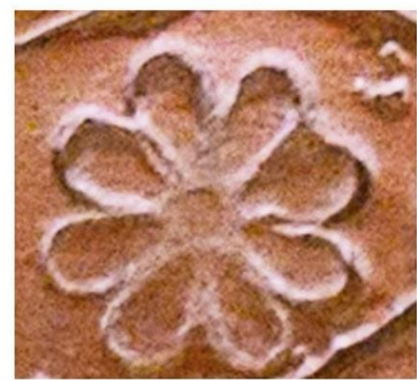

3. Ромашка или анемон 3. Chamomile or anemone

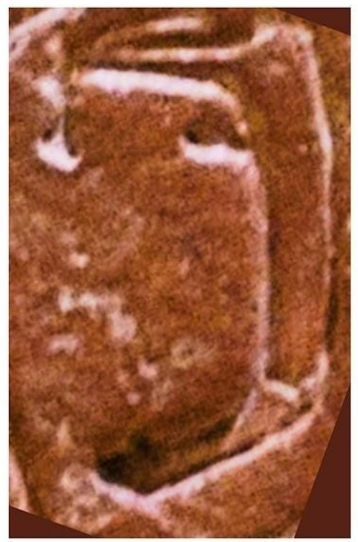

5. Корабль

5. Ship

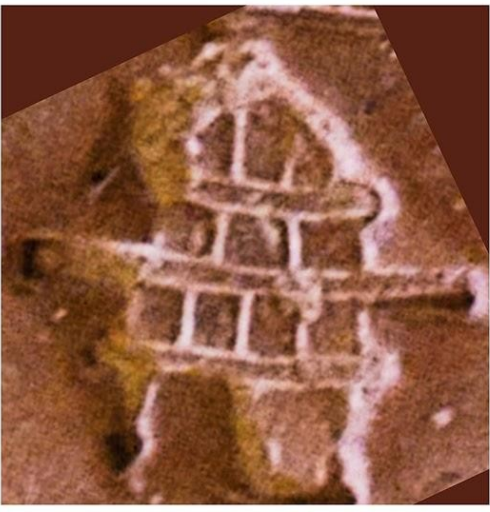

7. Дом на сваях

7. Stilt house
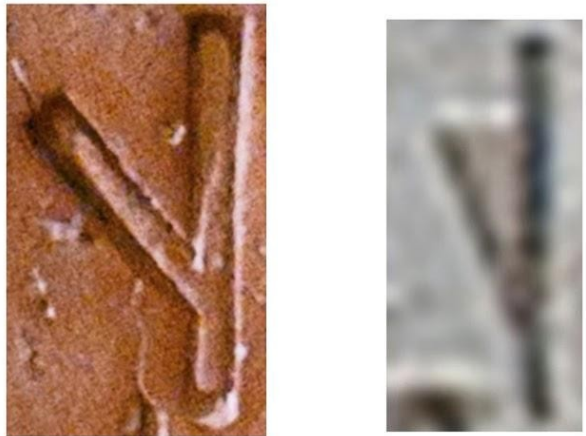

2. Измерительный инструмент

2. Measurement tool
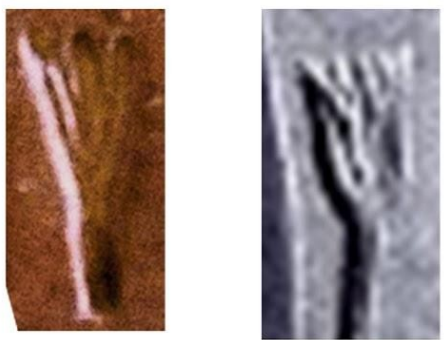

4 Крокус

4. Crocus

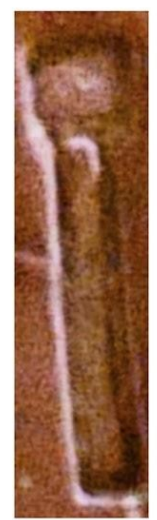

6. Колонна
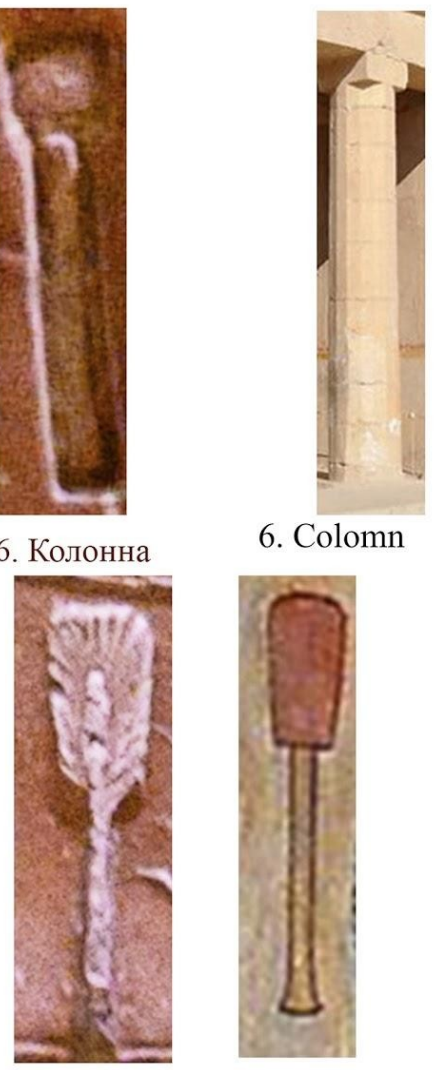

6. Colomn

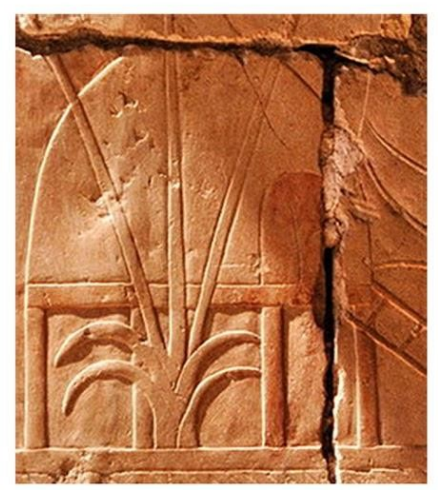

8. Инструмент

8. Tool

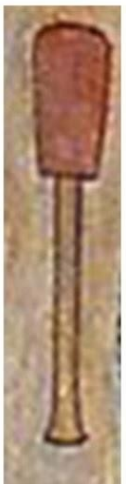


Таблица 2

Table 2. Cretan signs and corresponding Egyptian
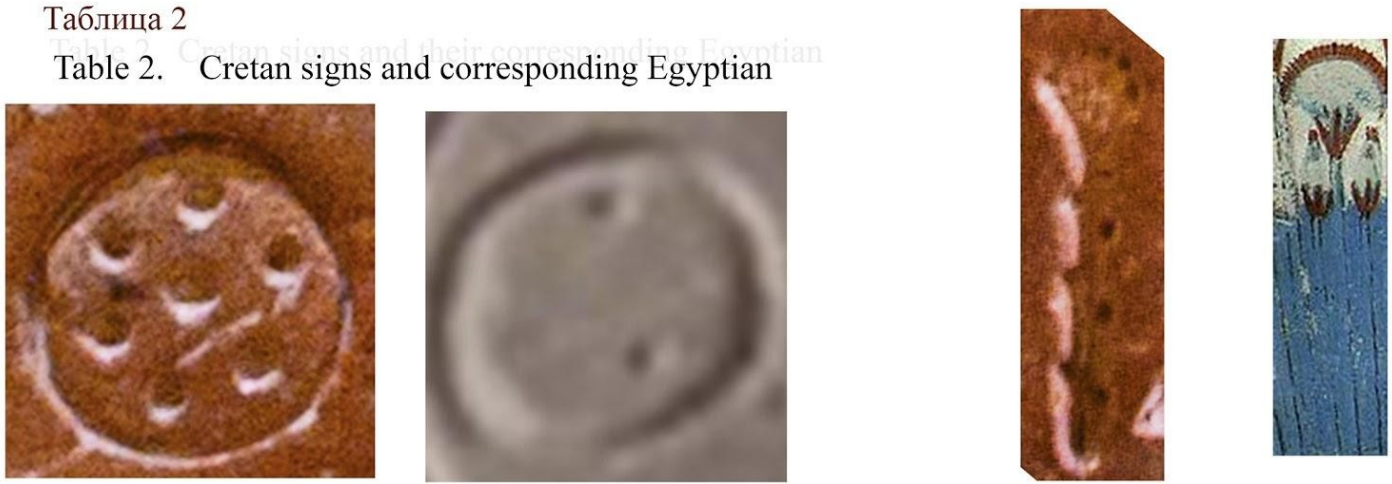

1. Щит или солнце

1. Shield or sun

2. Папирус

2. papyrus
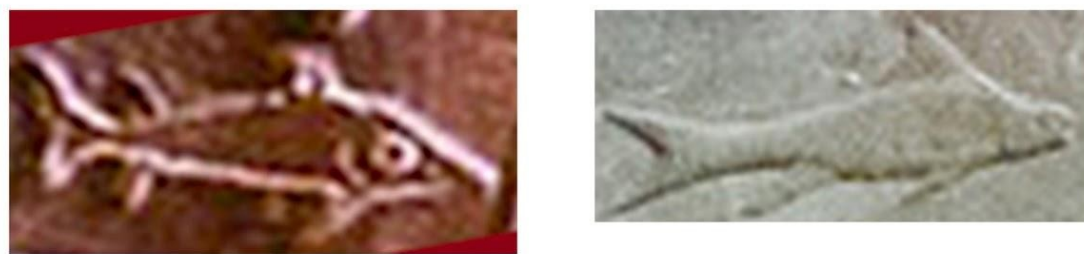

3. Рыба

3. Fish
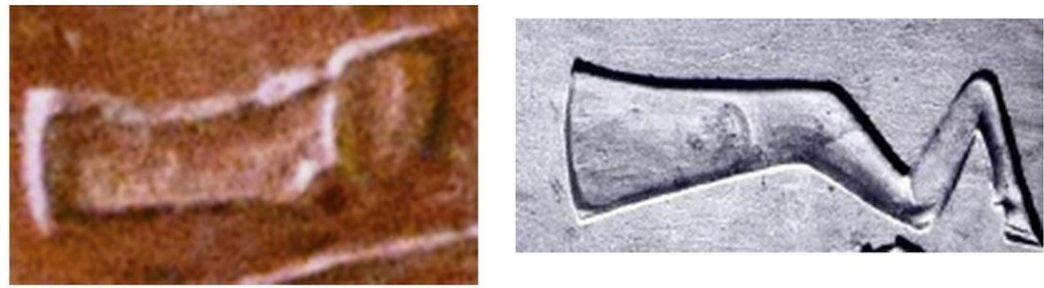

4. Нога копытного

4. ungulate foot

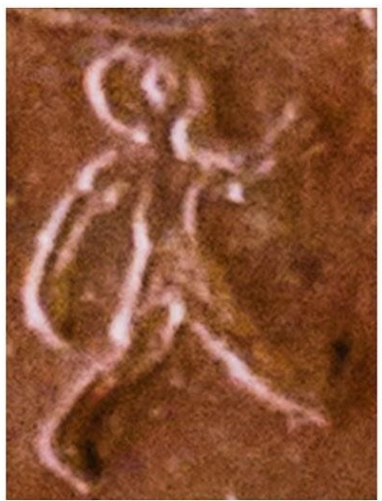

5. Шагающий человек

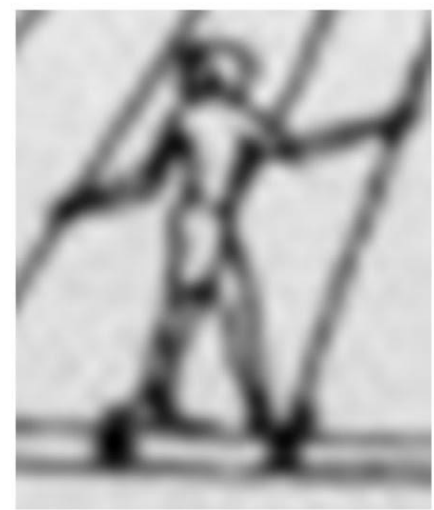

5. walking man
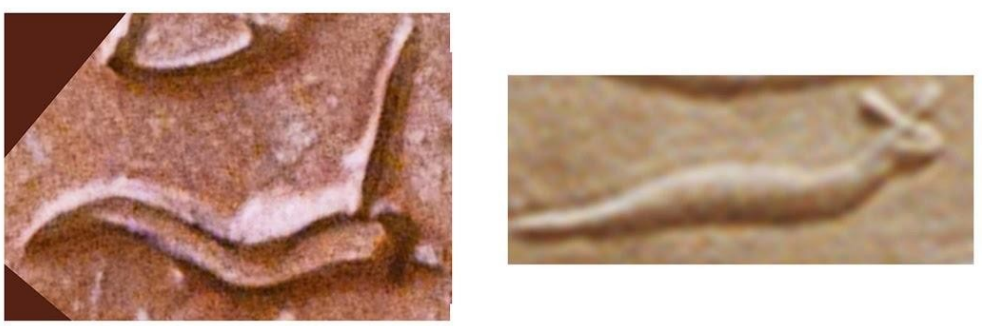

6. Snake or slug 
Таблица 3. Фестский диск: часть 1

Table 3. Phaistos disk. Part 1. Cretan signs and corresponding Egyptian
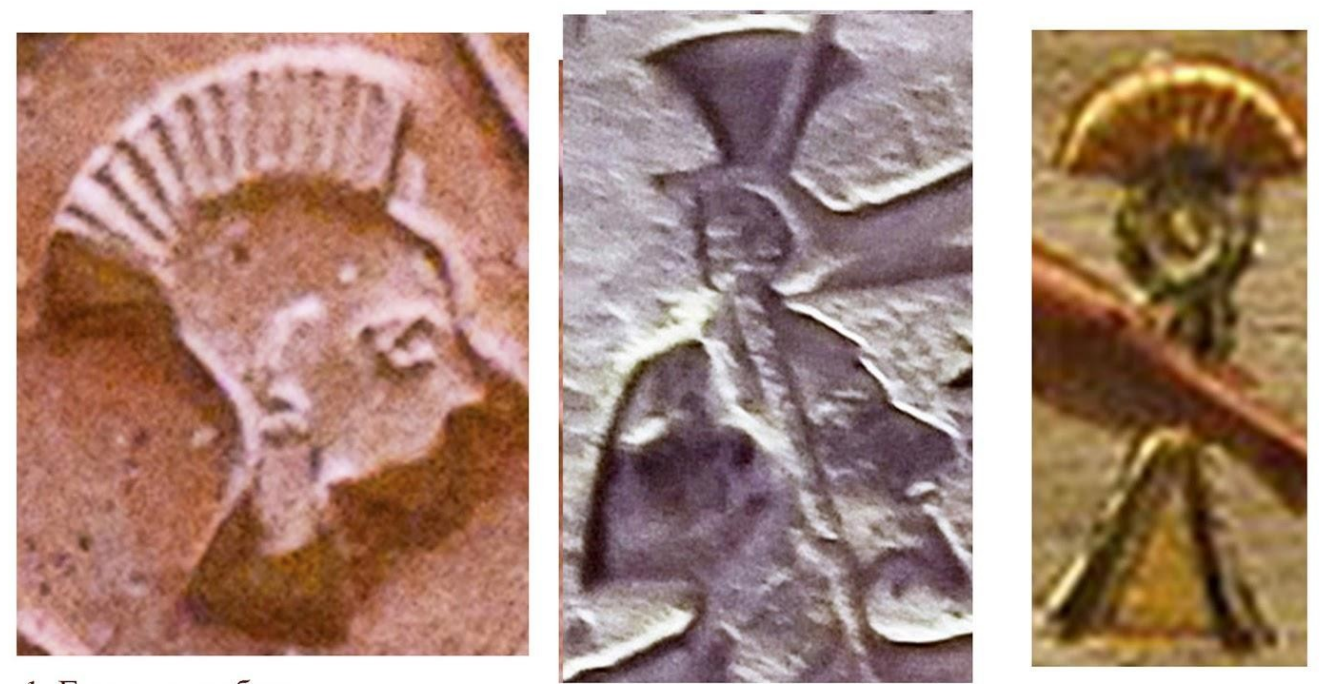

1. Голова с гребнем

1. Head with crest

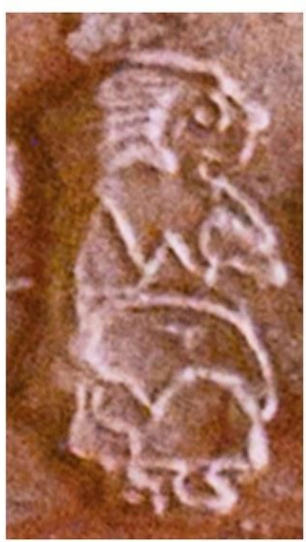

2. Женская фигура

2. Woman figura. Queen Punta Ani
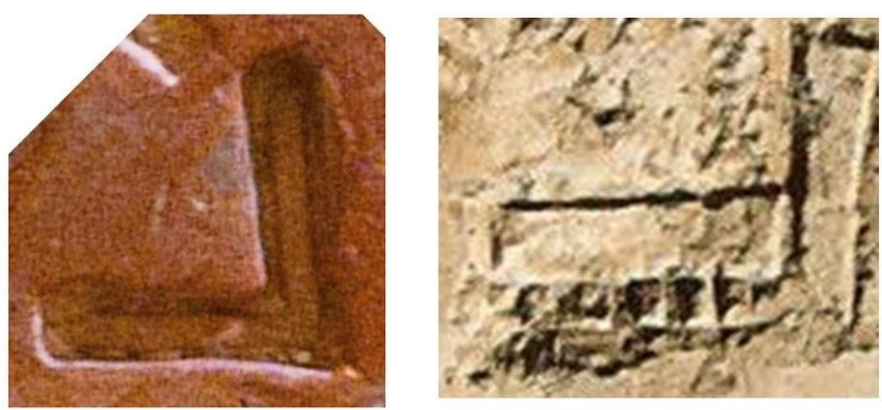

3. Плотницкий инструмент - уголок

3. Carpentry tool - angle

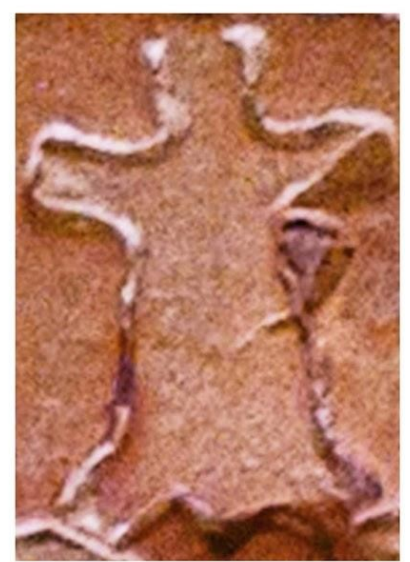

4. Шкура

4. Skin of animal
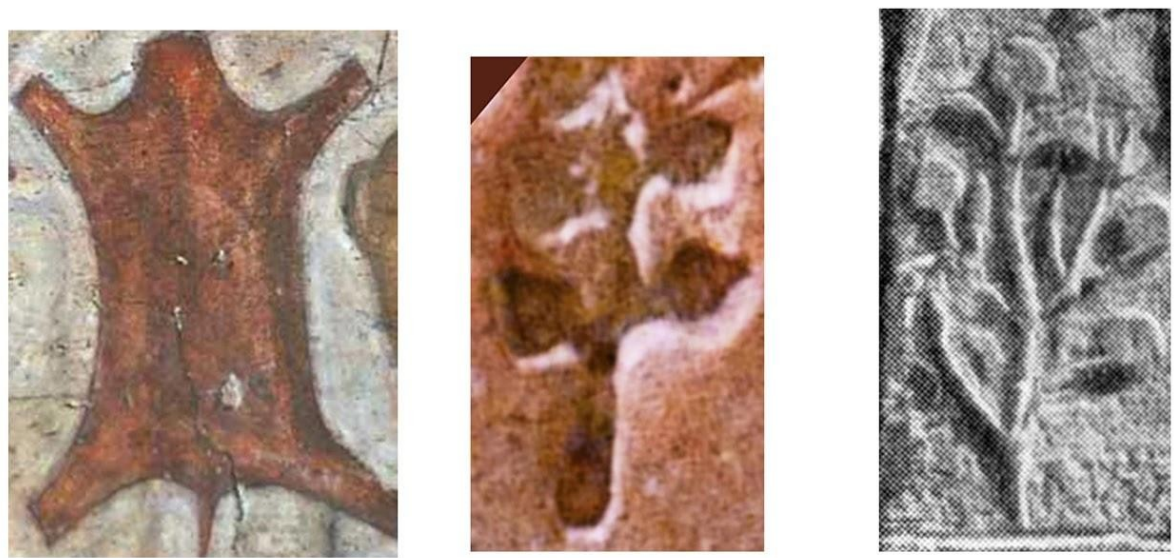

5. Ветвь куста или дерева

5. Bush or tree branch 
Таблица 4. Фестский диск: часть 2

Table 4. Phaistos disk. Part 2. Different styles of one sign
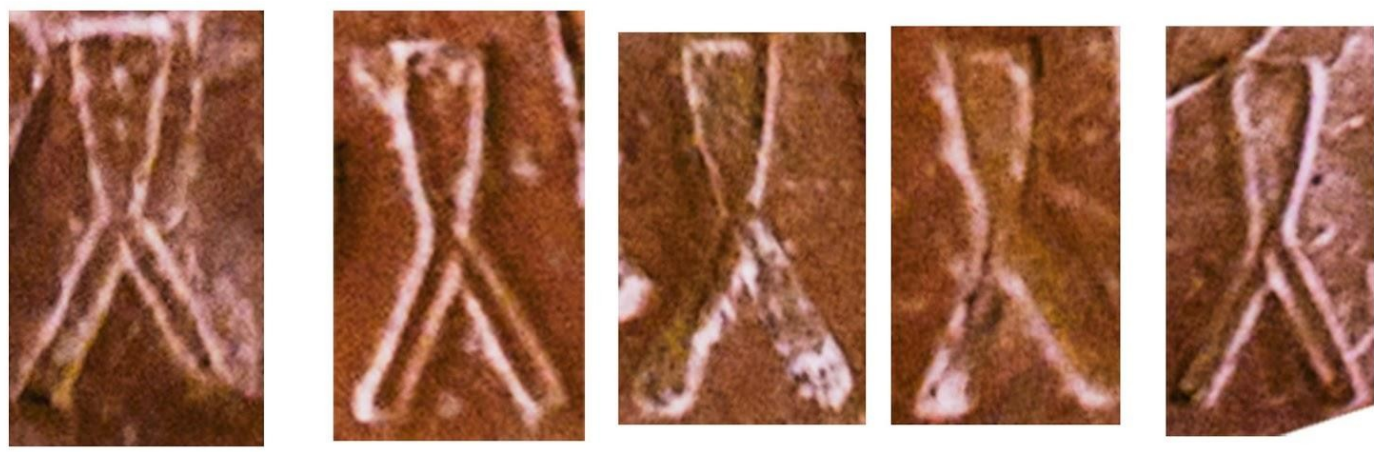

1. Корень растения

1. Root of plant or tool
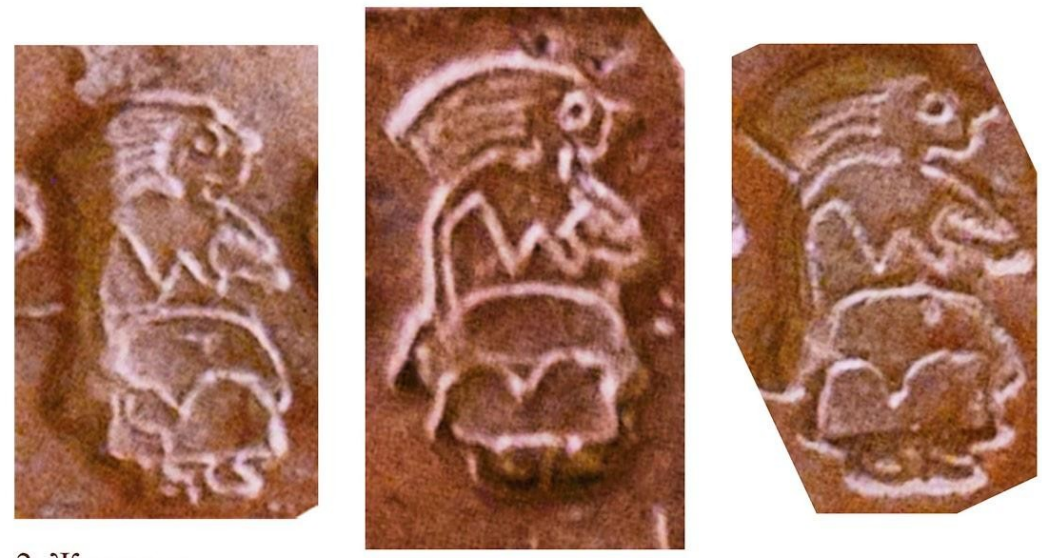

2. Женщина

2. Queen of Punt Ati or female figurine
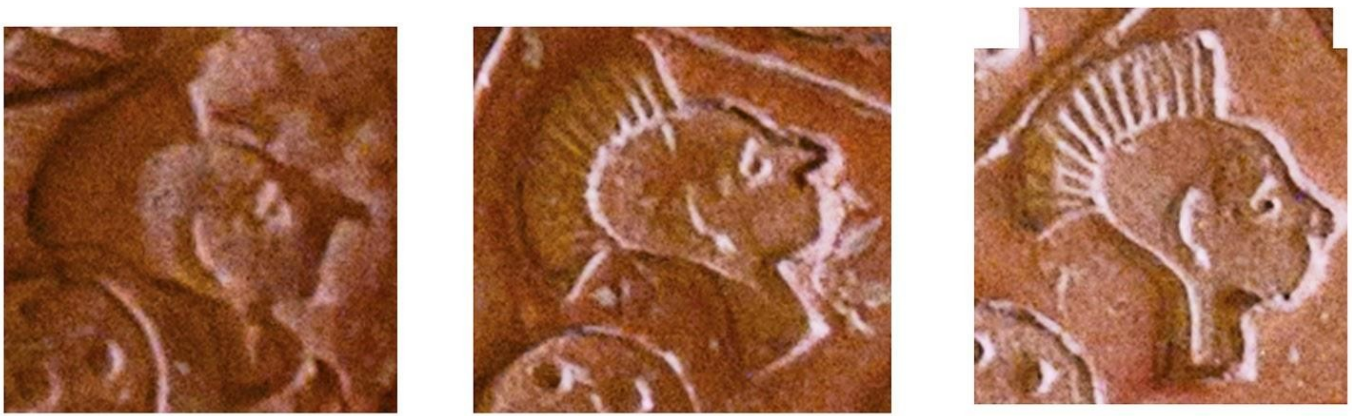

3. Голова с перьями

3. head with feathers 

Таблица 5. Фестский диск: часть 2

Table 5. Phaistos disk. Part 2. Sign Technology. line, point, hatching

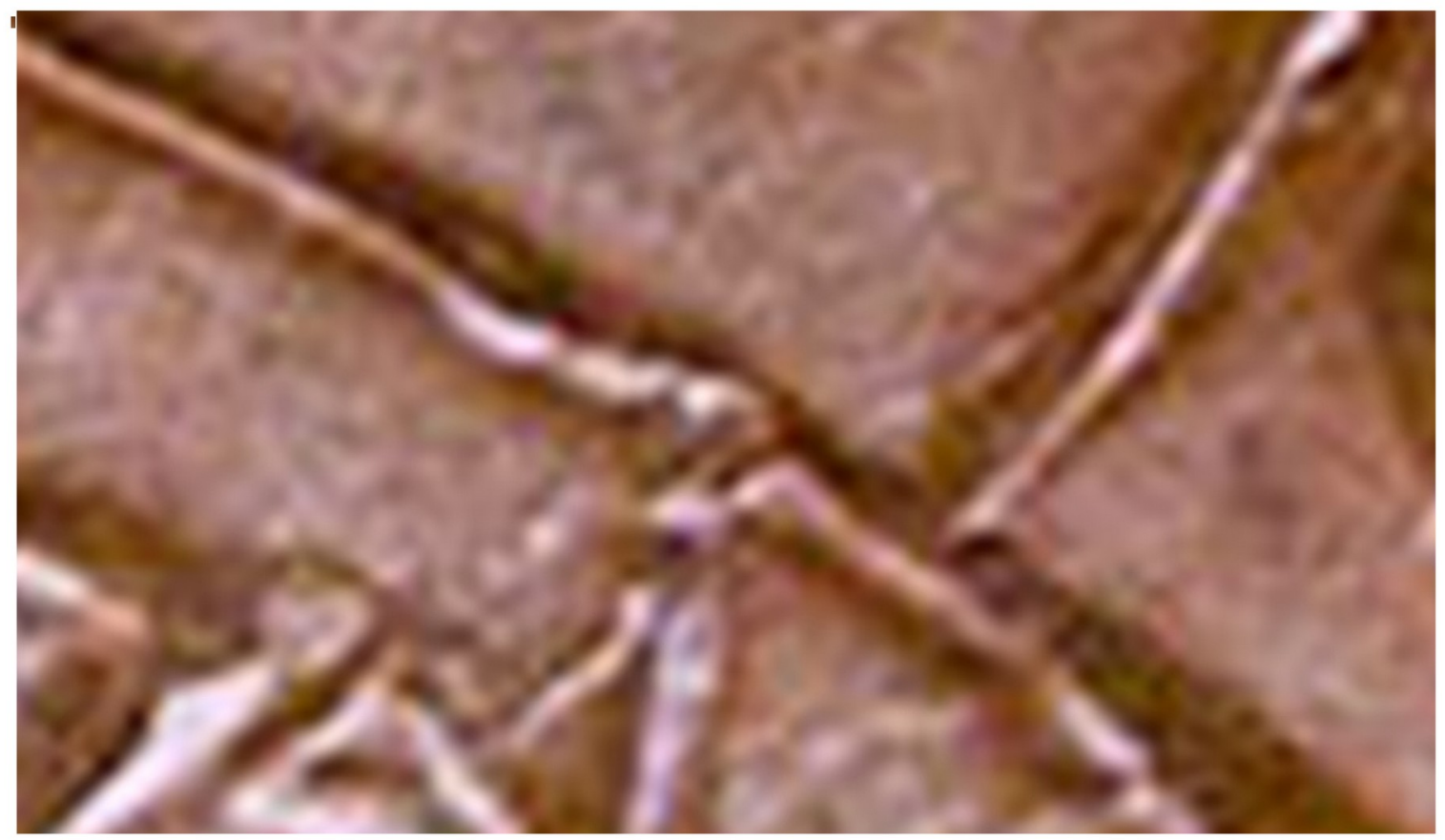

1. Разделительная линия сегментов

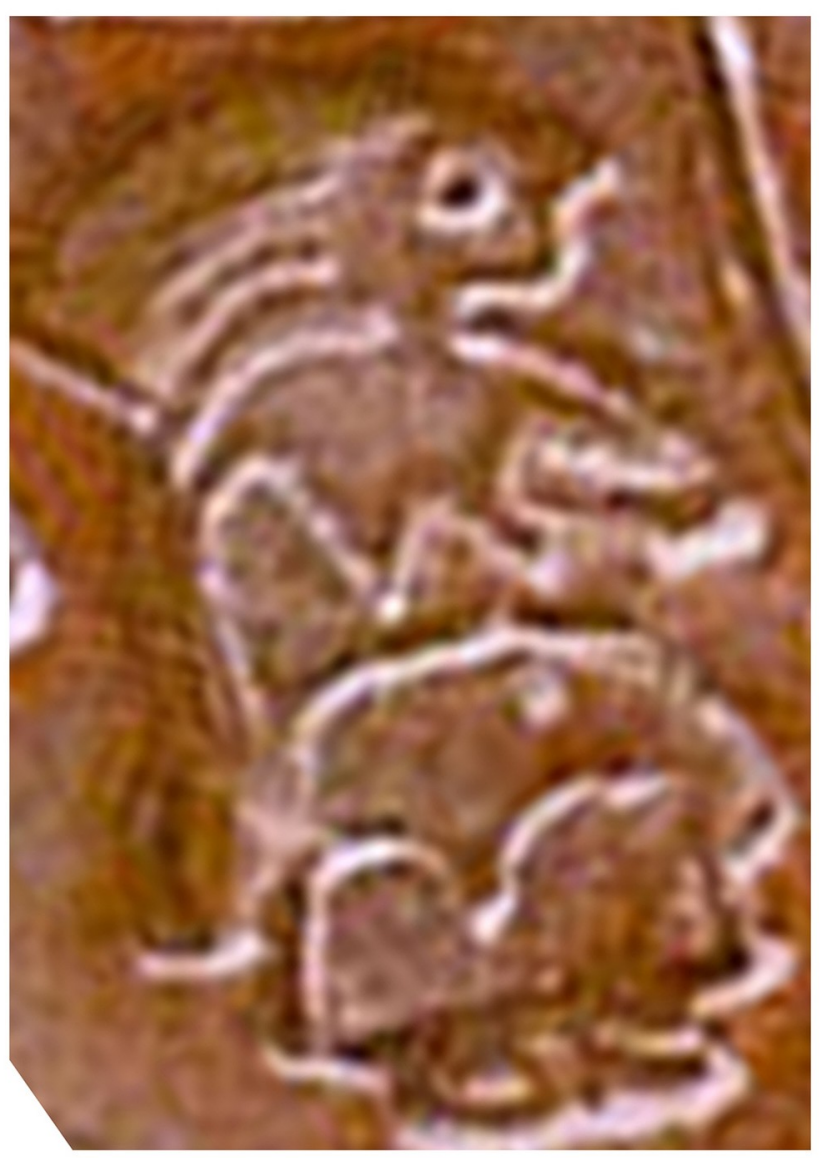

2. Царица Ати
1. Segment dividing line

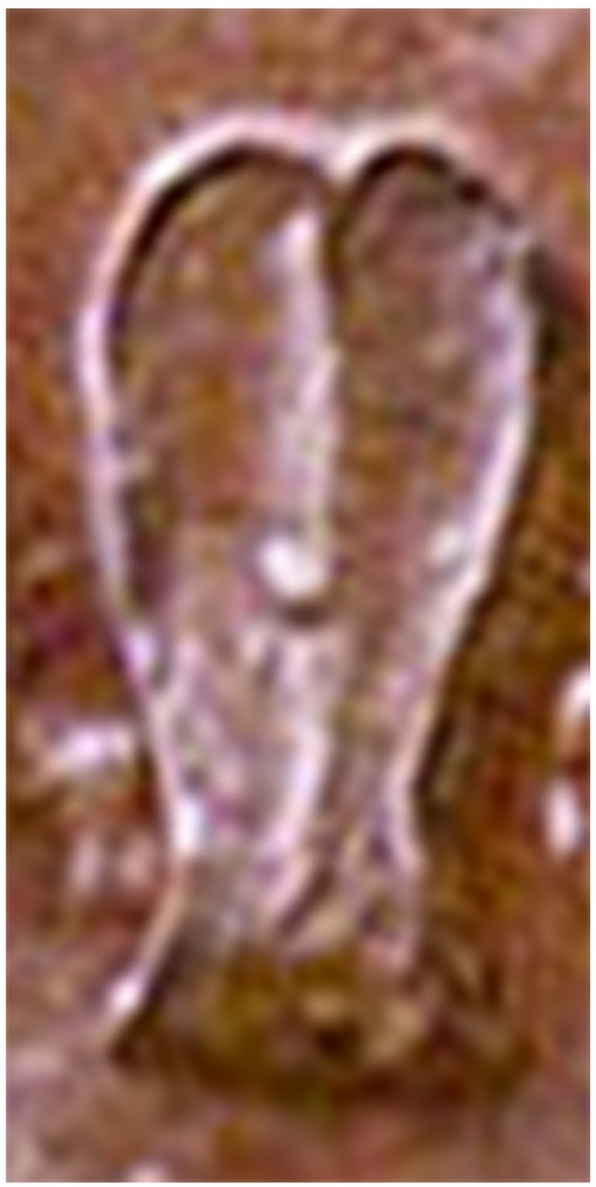

3. Домашнее животное сзади 

Таблица 6. Фестский диск: часть 3

Table 6. Phaistos disk. Part 3. Additional small images

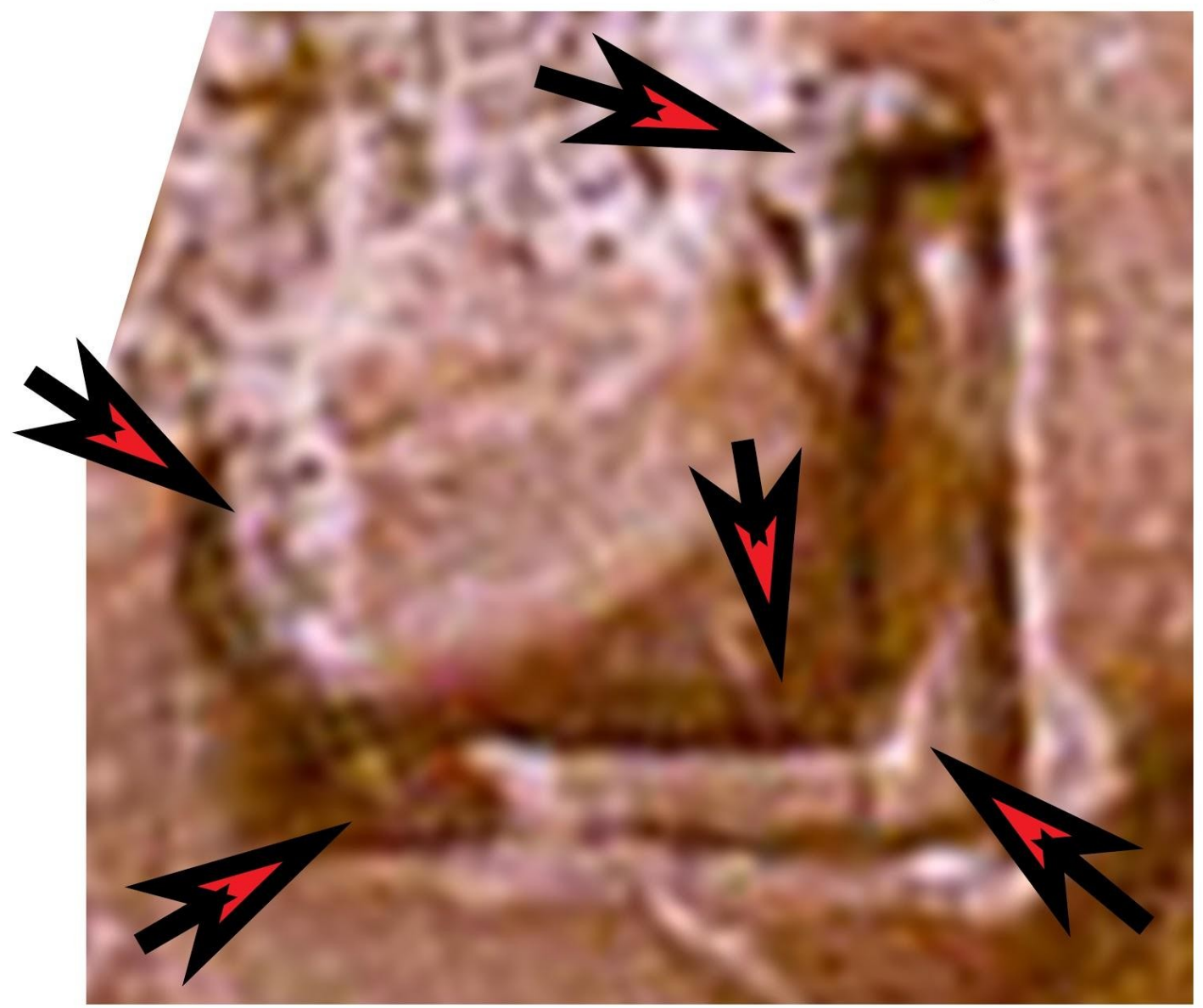

1.Left - snake, upper right - head of dog and other tiny signs

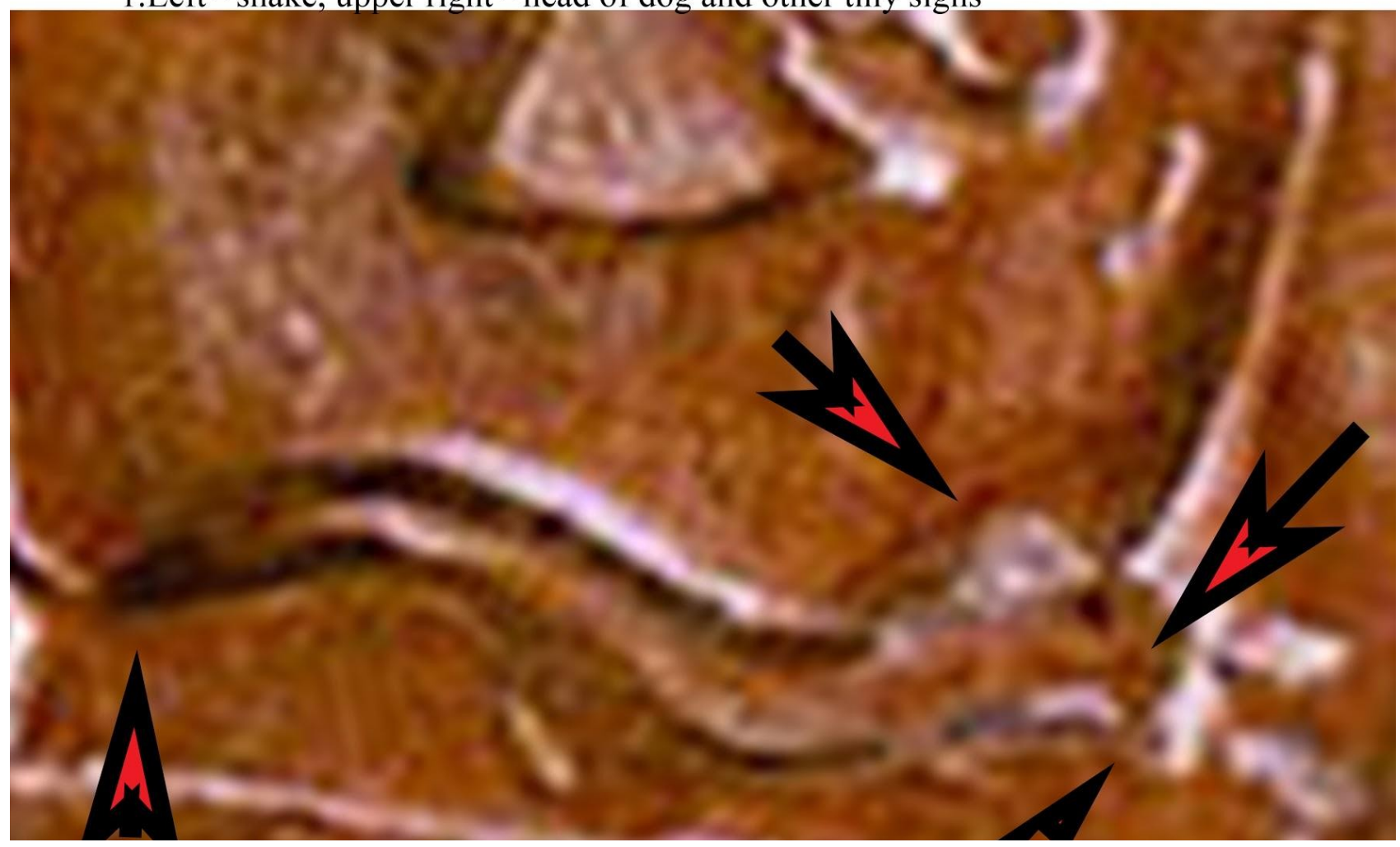


Таблица 7. Фестский диск: часть 3

Table 7. Phaistos disk. Part 3. Turn one character into different images
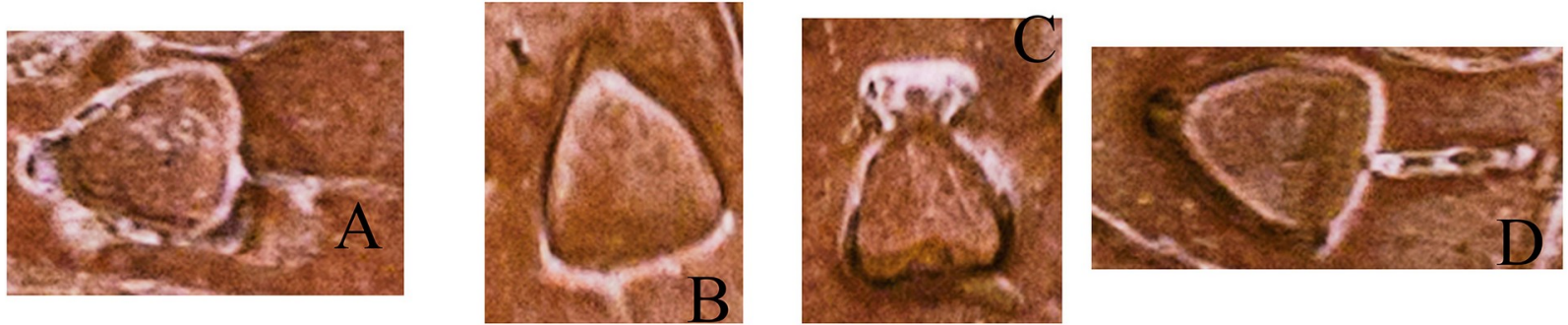

1. "Шлем" или мешок Превращенные в разные предметы

1. A helmet or a bag (B) becomes: a mouse (A), an insect (C) (a ladybug), and so on.
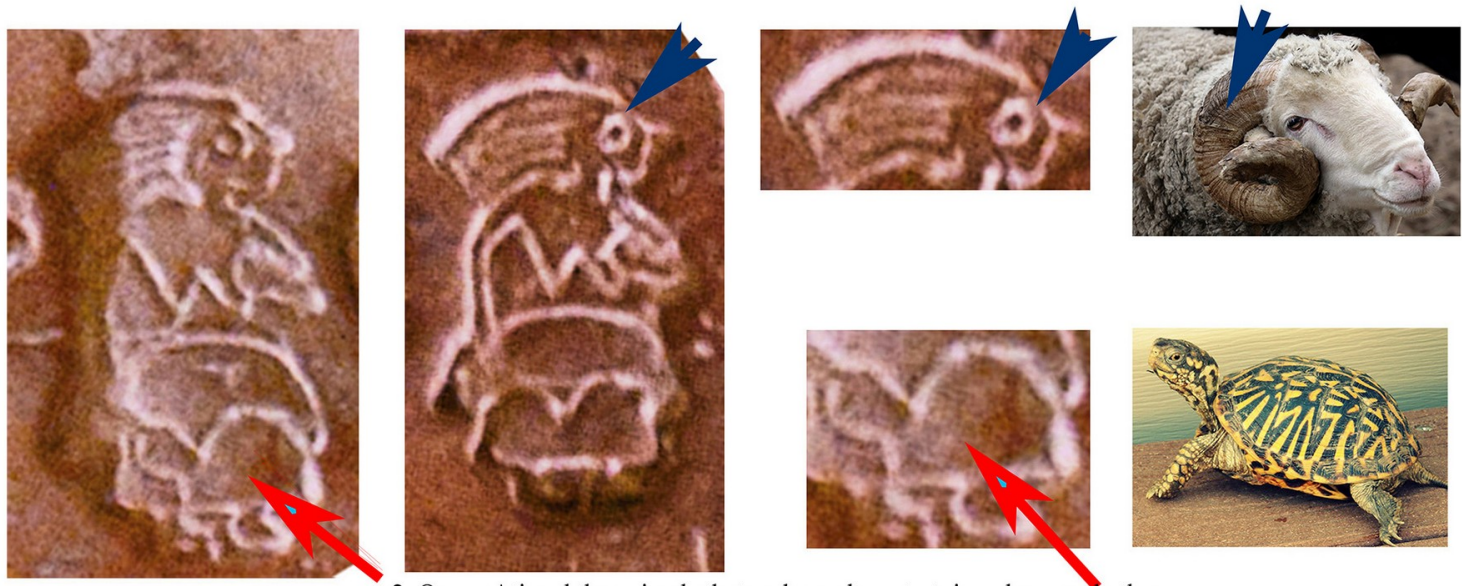

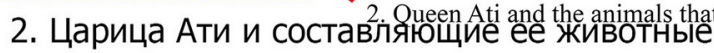
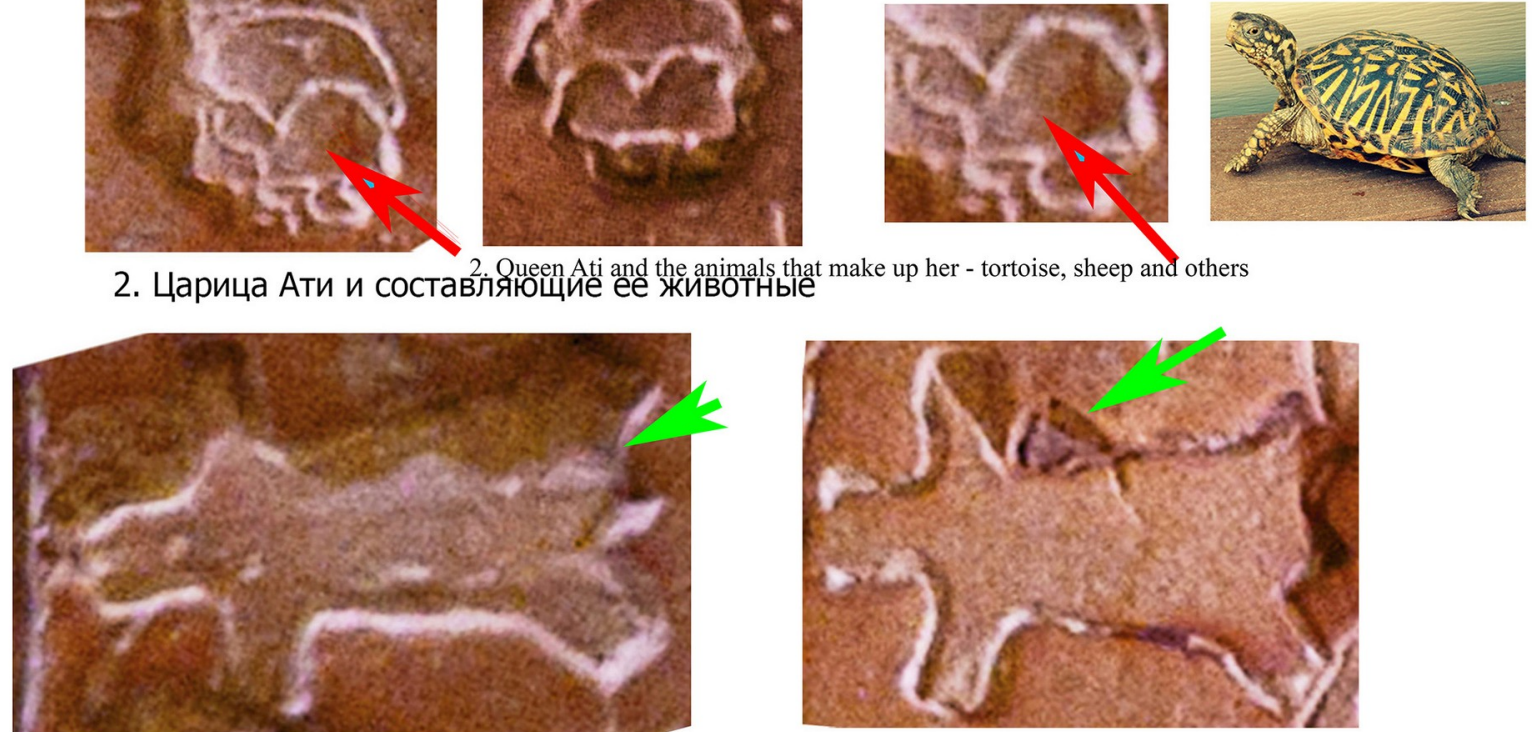

1
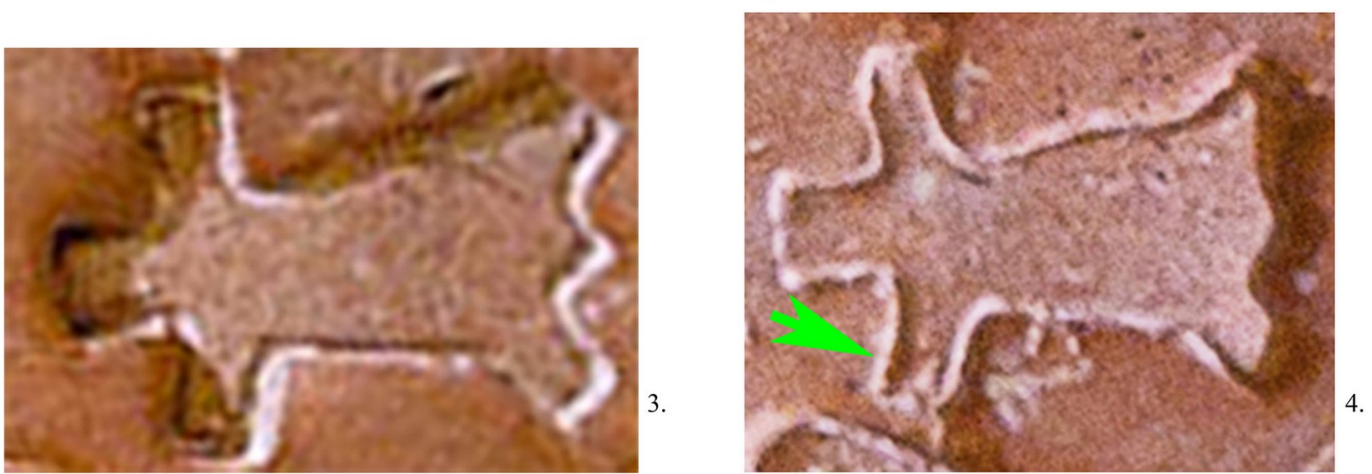

3. Шкура копытного животного с разными вариантами дополнений

3. The skin of an ungulate animal with various additions - lotus (2), snake (1), dog head (4) 
Таблица 8. Фестский диск: часть 3

Table 8. Phaistos disk. Part 3. The origin of the signs - resemblance to Egyptian techniques

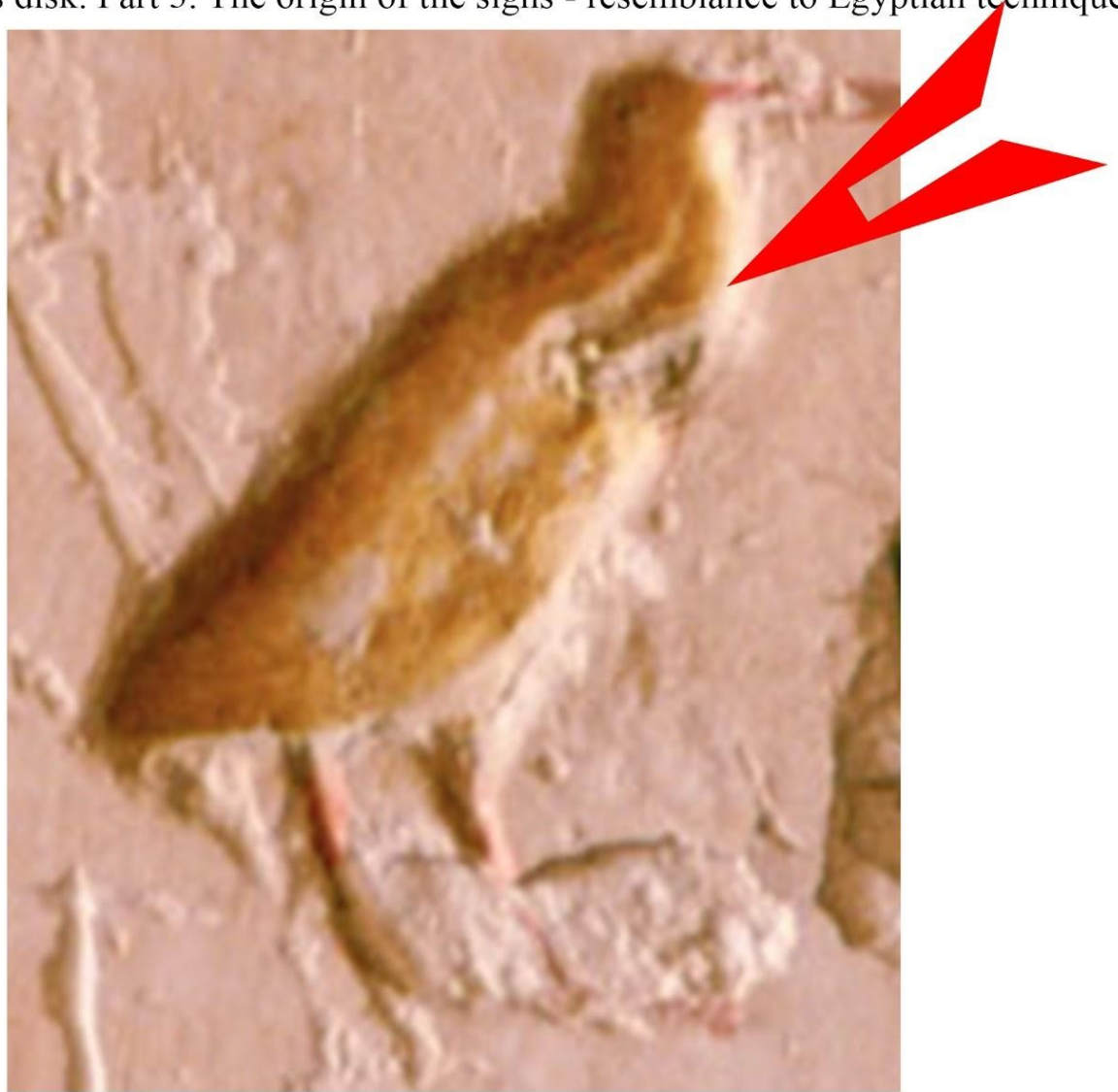

1. Bird from Karnak Temple. Her brest made like shark body

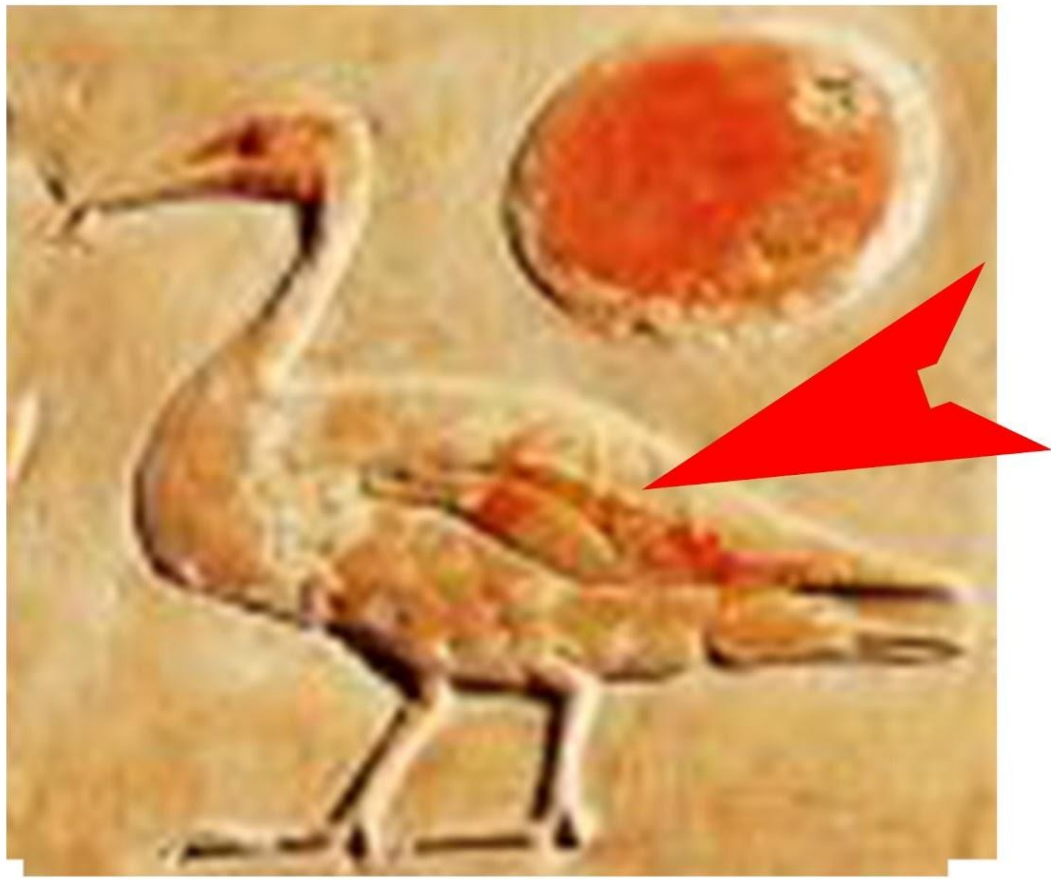

2. Bird from Luxor Temple. Its wing made like smaller bird and insect. 
Таблица 9. Фестский диск: часть 4 Table 9. Possible Disc Precursors.
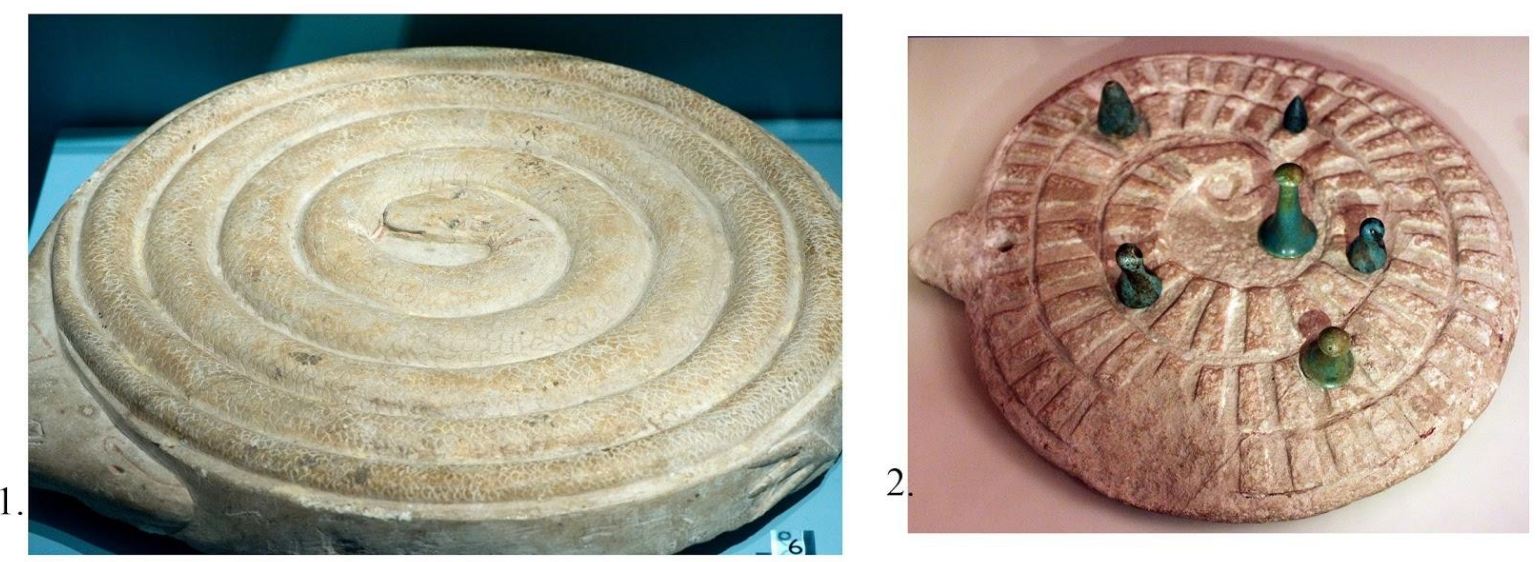

1,2.3. Каменные диски для игры в Мехен. Древнее царство.

1.2.3. Stone disc to play Mehen

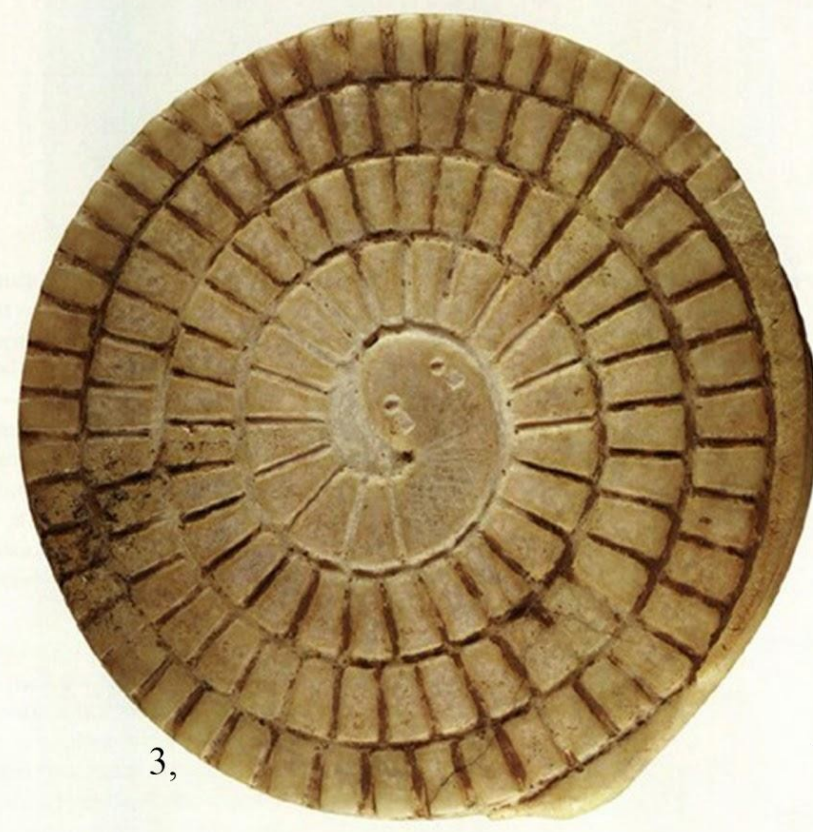

4.

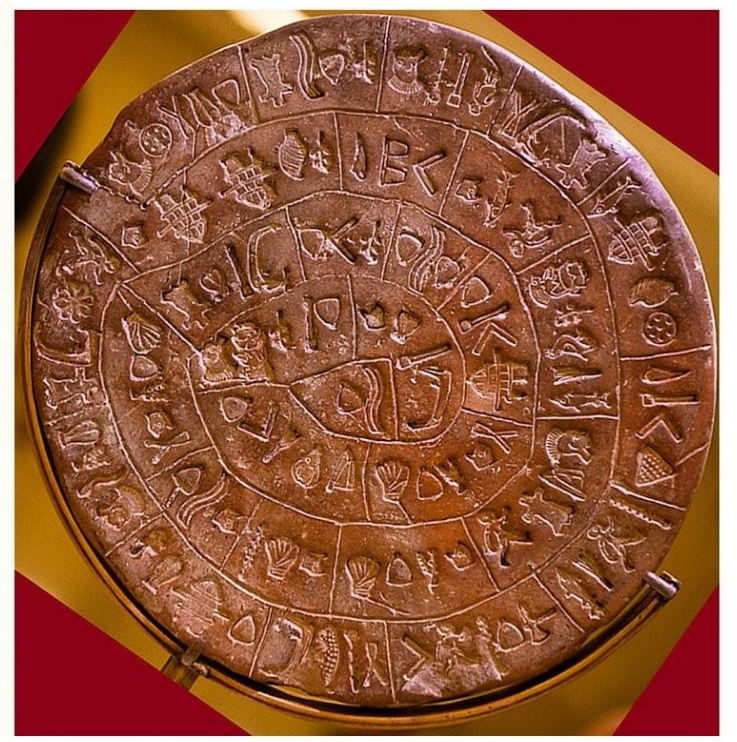

4. Phaistos Disk. Made like snake. Head in the

2. Центр диска из Феста: голова змеи

5. Center of Phaistos disc - snake head with eye

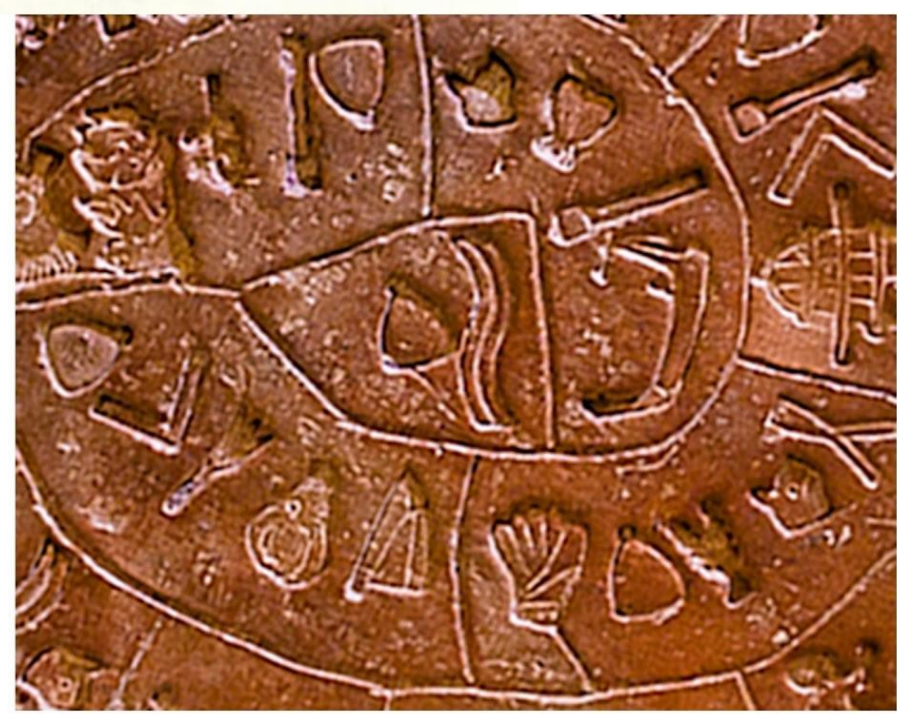
center. 
Таблица 10. Часть 4. Назначение диска - оракул.

Table 10. Part 10. The purpose of the disk is oracle. Prediction of the future, fortune telling

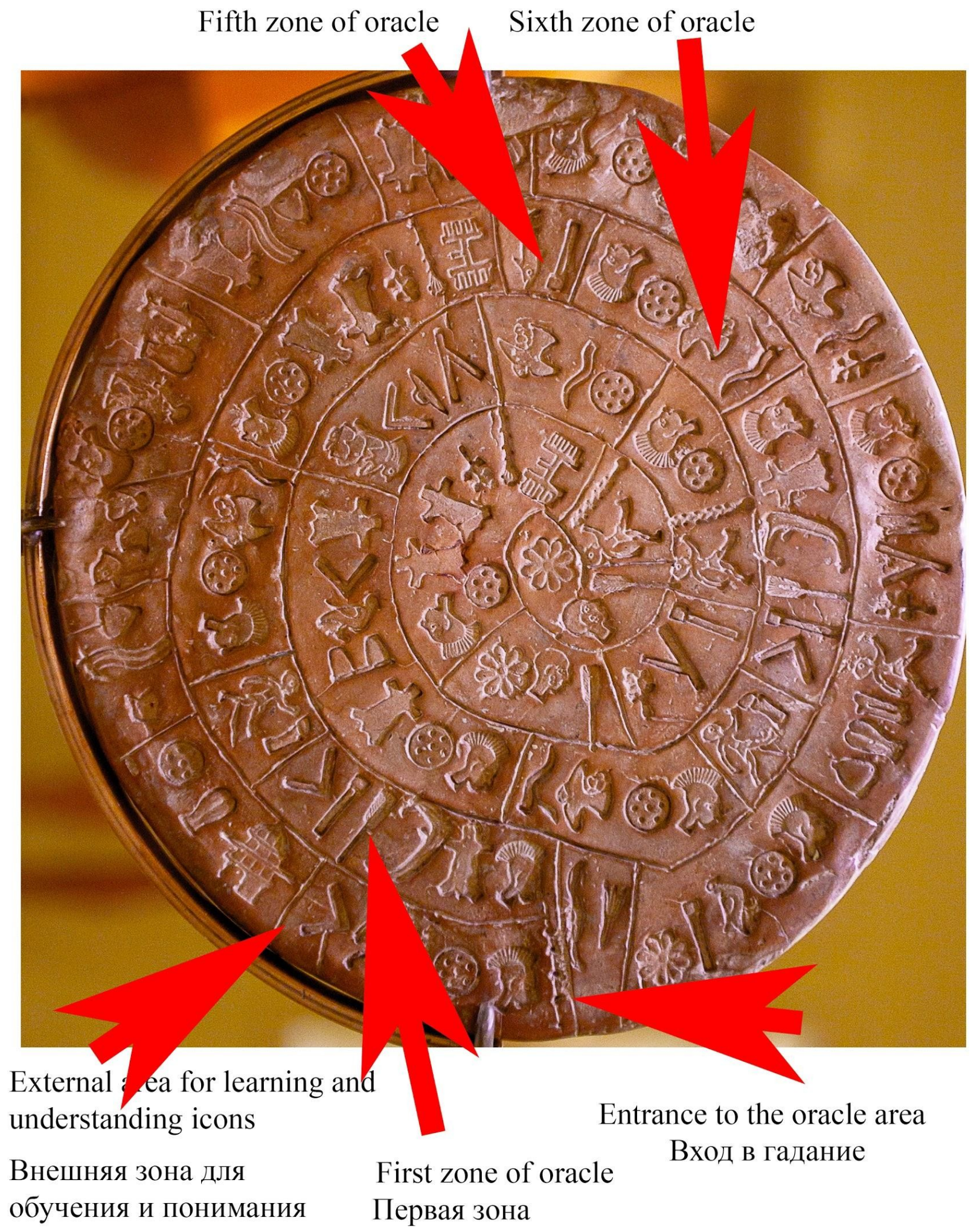




\section{Таблица 11. Фестский диск. Часть 4}

Table 11. Phaistos disk. Part 4. Imagine: What awaits me in the new year? Possible pictographic answers

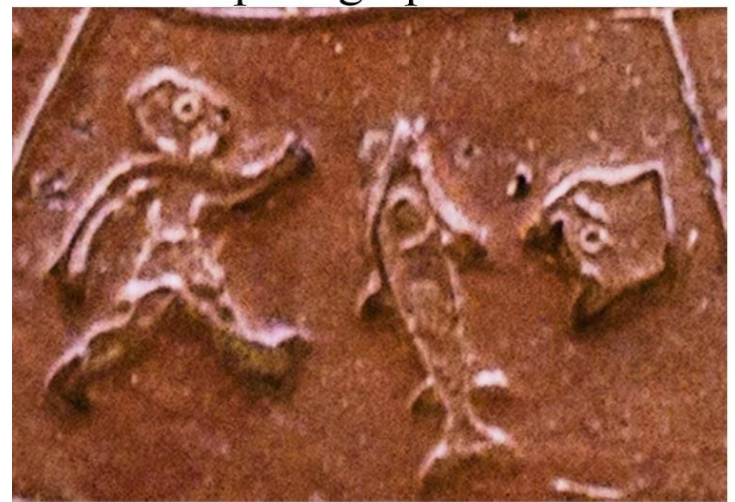

1.You will go to a place where there is a quiet life with pets and fishing

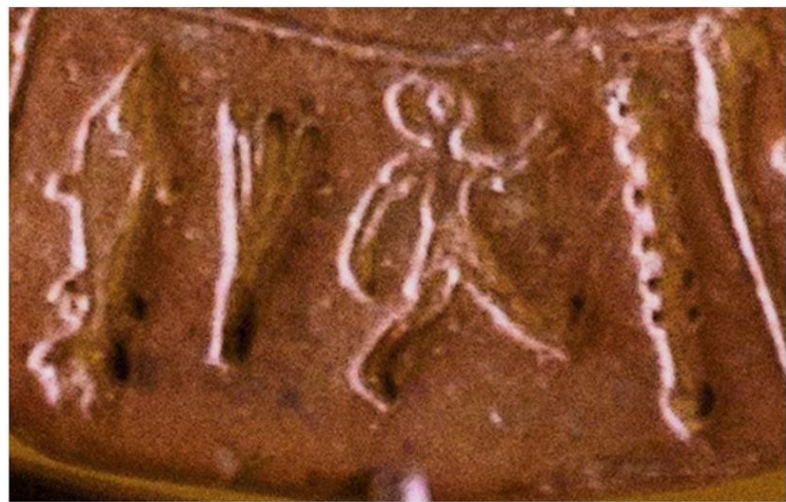

2. Trip in the place where crocuses and cyprisses, and lots of fish

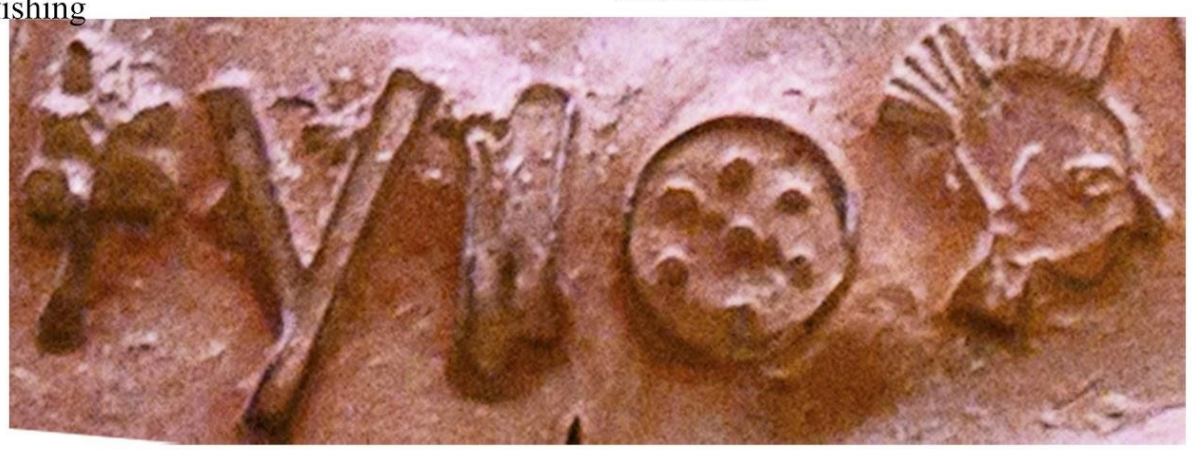

3. You will be surrounded with music and servants, with acres of beautiful trees

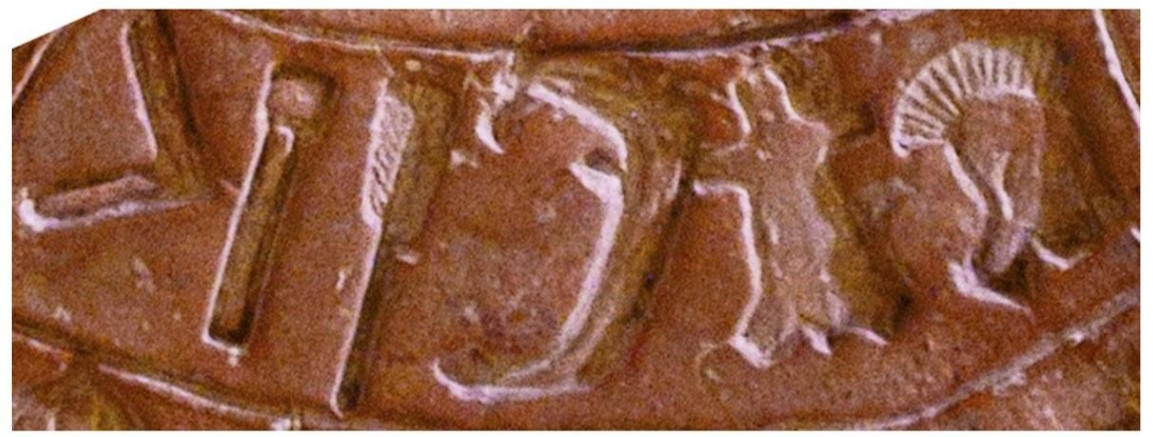

4. Trip into a new land by ships. Rich boot waits for you - many slaves, treasures, peaces of art and craft.

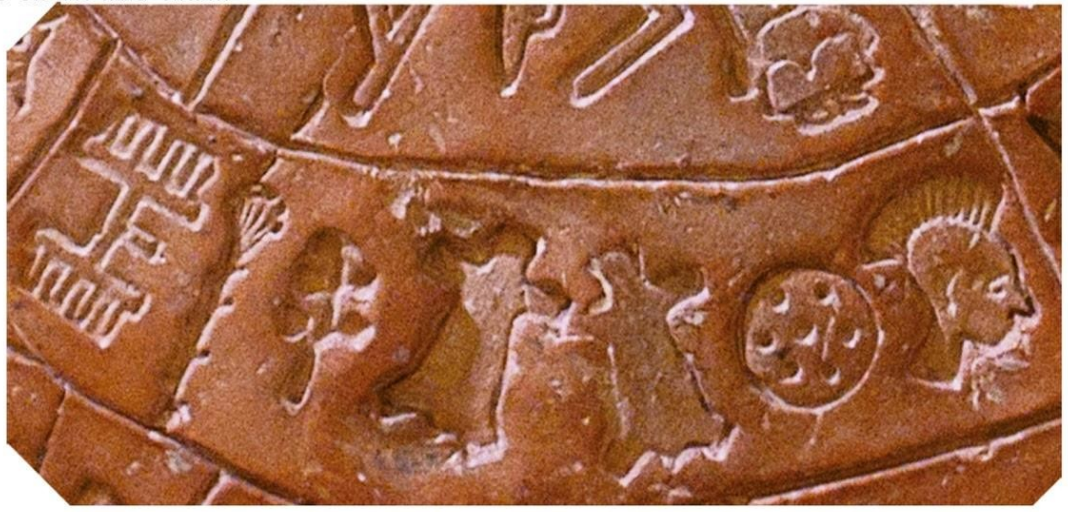


Литература

1. Откупщиков Ю. В. Фестский диск: Проблемы дешифровки. Издательский дом СПбГУ. - СПб. 2000. -140 с.

2. Chadwick, J. The Decipherment of Linear B. - Cambridge: Cambridge University Press. - 1958. - 240.

3. Pernier L. Il disco di Phaestos com caratteri pittografici. Архивная копия от 14 ноября 2008 года на Wayback Machine. — Ausonia: 1908. Vol. 3. - Roma, 1909. P. 255-302.

4. Meyer Ed. Der Discus von Phaestos und die Philister von Kreta // Sitzungsberichte der königl. preussischen Akademie der Wissenschaften: Philosophisch-historische Classe. Berlin, 1909. S. 1024.

5. Jeppesen, Kristian. En gammelkretisk gåde, Kuml. 1962 (1963).

- $\quad$ Bern - P. 157-190

6. Тайны древних письмён. Проблемы дешифровки.

Сборник статей. - М.: Наука. 1976. - 592 с.

7. Андреев Ю.В. От Евразии к Европе. Крит и Эгейский мир в эпоху бронзы и раннего железа (III — СПб.: Дмитрий Буланин, 2002. — 864 с.

8. Ipsen. Der Diskus von Phaistos // Indogermanische Forschungen. 47. - London. - 1929

9. Добльхофер Э. Знаки и чудеса. - М.: Вече, 2004. 432 c.

10. Кондратов А.М. Шеворошкин В.В. Когда молчат письмена. - М.: Прогресс. - $1970 .-228$ с

11. Фридрих, И. Дешифровка забытых письменностей и языков. - М.: 2007. - 210 с.

12. Arthur Evans. The palace of Minos. - Oxford: 1909. -

P. $\quad 647-668$

13. Evans, A. The palace of Minos: a comparative account of the successive stages of the early Cretan civilization as illustrated by the discoveries at Knossos. Vol. 1. - London. - 1921. - P. 239

\section{Literatura}


1. Otkupshchikov Yu. V. Festskij disk: Problemy deshifrovki. Izdatel'skij dom SPbGU. - SPb. 2000. - $40 \mathrm{~s}$.

2. Chadwick, J. The Decipherment of Linear B. - Cambridge: Cambridge University Press. - 1958. - 240.

3. Pernier L. Il disco di Phaestos com caratteri pittografici. Arhivnaya kopiya ot 14 noyabrya 2008 goda na Wayback Machine. — Ausonia: 1908. Vol. 3. - Roma, 1909. P. 255-302.

4. Meyer Ed. Der Discus von Phaestos und die Philister von Kreta // Sitzungsberichte der königl. preussischen Akademie der Wissenschaften: Philosophisch-historische Classe. Berlin, 1909. S. 1024.

5. Jeppesen, Kristian. En gammelkretisk gåde, Kuml. 1962 (1963). - Bern - P. $157-190$

6. Tajny drevnih pis'myon. Problemy deshifrovki. Sbornik statej. - M.: Nauka. 1976. - $592 \mathrm{~s}$.

7. Andreev Yu.V. Ot Evrazii k Evrope. Krit i Egejskij mir v epohu bronzy i rannego zheleza (III - nachalo I tysyacheletiya do n. e.). - SPb.: Dmitrij Bulanin, 2002. -864 s.

8. Ipsen. Der Diskus von Phaistos // Indogermanische Forschungen. 47. - London. $-1929$

9. Dobl'hofer E. Znaki i chudesa. — M.: Veche, 2004. — 432 s.

10. Kondratov A.M. Shevoroshkin V.V. Kogda molchat pis'mena. - M.: Progress. - 1970. - $228 \mathrm{~s}$

11. Fridrih, I. Deshifrovka zabytyh pis'mennostej i yazykov. — M.: 2007. — 210 S.

12. Arthur Evans. The palace of Minos. - Oxford: 1909. - P. 647—668

13. Evans, A. The palace of Minos: a comparative account of the successive stages of the early Cretan civilization as illustrated by the discoveries at Knossos. Vol. 1. - London. - 1921 
